Original article

\title{
EPIDEMIOLOGY OF LUNG PARASITES OF EUROPEAN BROWN HARE (LEPUS EUROPEUS L.) FROM BULGARIA
}

\author{
M. S. PANAYOTOVA-PENCHEVA ${ }^{1}$, A. P. TRIFONOVA ${ }^{2}$, V. I. DAKOVA ${ }^{1}$ \\ \& CH. ZHELEV ${ }^{2}$ \\ ${ }^{1}$ Institute of Experimental Morphology, Pathology and Anthropology with \\ Museum, Bulgarian Academy of Sciences, Sofia, Bulgaria; ${ }^{2}$ South-West State \\ Enterprise, Sofia, Bulgaria
}

\section{Summary}

Panayotova-Pencheva, M. S., A. P. Trifonova, V. I. Dakova \& Ch. Zhelev, 2019. Epidemiology of lung parasites of European brown hare (Lepus europeus L.) from Bulgaria. Bulg. J. Vet. Med., 22, No 4, 478-486.

During the period 2009-2016, seven hundred and ninety lungs from brown hares (Lepus europeus L.) from different regions of Bulgaria were investigated for presence of parasites. The results showed that $11.14 \%$ of the lungs were parasitised. Four parasite species were established: two nematodes - Protostrongylus tauricus and P. cuniculorum (recorded for the first time as a part of the helminth fauna of the country), one cestod - larval form of Taenia pisiformis - Cysticercus pisiformis and one arthropod - larval form of Linguatula serrata - Pentastomum denticulatum. The infected hares came mainly of the south parts of the country. The highest prevalence of infection was observed in the South West region, followed by the South Central and South East regions. From the northern parts of the country parasites were established only in the northeastern districts near to Black Sea and Danube River. The ratio of prevalence of infection in female vs male animals was 1.4:1. Infections with protostrongylids and cysticerci were established at the earliest in hares at the age of 4-6 months and with P. denticulatum: in hares between 7 and 9 months. The prevalence of infection varied in animals from the different age groups. The highest prevalence of infection was observed in the young (4-6 months) and adult hares (over 3 years of age).

Key words: Bulgaria, Cysticercus pisiformis, Lepus europeus, lung parasites, Protostrongylus tauricus, P. cuniculorum, Pentastomum denticulatum

\section{INTRODUCTION}

Brown hare is one of the basic game species in Bulgaria. During the last years a growing interest to the status of its population is observed by reason of the permanent decrease of its number in many hunt- ing grounds. In 2012, the number of brown hares in the country was about $34 \%$ of this in 1974 and the use of hares as hunting objects was reduced from $5.9 \%$ in 2004 to $3.7 \%$ in 2011 (Trifonova \& Mir- 
chev, 2013). The analysis of data from the information system of the Executive Forestry Agency of the Ministry of Agriculture and Food of the Republic of Bulgaria on the number of brown hares in Bulgaria during 2007-2017 years showed a clear tendency towards continuous decrease.

Reduction in the hare population, which is noticed in whole Europe too, can be caused by changed living conditions, insufficient quantity and quality of nutrition, increased use of herbicides as well as various infectious diseases including parasitoses (Ilić et al., 2014). For instance Alzaga et al. (2008) have found correlation between parasite infection intensity of hares and their anti-predator escape capacity. According to Chroust et al. (2012) parasitic infections of the lungs and intestines influence the health and decrease the body weight of hares in Austrian and Czech hunting grounds. Other authors (Lesage et al., 2014) consider that pulmonary parasitoses, such as protostrongylidoses, are among the most dangerous diseases in hares that in determined conditions can be a reason influencing their number. It has been found that infection intensity with the lungworm Protostrongylus tauricus can reach several thousand specimens in one animal and cause severe injuries of the lungs as atelectasis, emphysema and necrosis. This leads to damage of the respiratory function of the lungs, losing weight of the animals, decreased mobility and death cases (Genov, 1970; Boev, 1975). On the other hand brown hare is a natural reservoir for some dangerous helminthoses for humans and domestic animals (Chaignat et al., 2015; Cuervo et al., 2015;).

In connection with the above mentioned we set a goal to study species composition of the parasites affecting lungs of brown hares in Bulgaria and their distribu- tion, as well as some epidemiological aspects of the established parasitoses.

\section{MATERIALS AND METHODS}

During the period 2009-2016 seven hundred and ninety lungs from brown hares (Lepus europeus L.) were investigated for presence of parasites. The animals came from 24 districts of Bulgaria: Blagoevgrad, Burgas, Varna, Veliko Tarnovo, Vidin, Vratsa, Dobrich, Kardzhali, Lovech, Pazardzhik, Pleven, Plovdiv, Razgrad, Ruse, Silistra, Sliven, Smolyan, Sofia, Sofia city, Stara Zagora, Targoviste, Haskovo, Shumen and Yambol.

Materials were obtained mainly by plan shot animals (according to the Law of Hunting and Game Conservation, 2000) and at a small extent from hares found dead.

The age of the animals was determined as described by Zhelev (2015). Hares were divided into 7 age groups: 0-3 months, 4-6 months, 7-9 months, 10-12 months, 1-2 years, 2-3 years, over 3 years of age.

The lungs have been separated from the carcasses, put in deep freeze and subsequently sent for necropsies in laboratory conditions.

The parasites from trachea and bronchi were collected in a physiological saline and stored in $70 \%$ ethanol. The specimens used for identification were cleared in alcohol-glycerol sequence or with lactophenol. To find small, hardly visible worms located in the bronchioles and alveoli, the abnormal lung tissues were examined as described in previous work (Panayotova-Pencheva, 2011). The obtained specimens were deposited in the collection of the Institute of Experimental Morphology, Pathology and Anthropo- 
logy with Museum, Bulgarian Academy of Sciences, Sofia, Bulgaria.

\section{RESULTS}

The following parasites were established in the lungs of hares: two nematode spe- cies - Protostrongylus tauricus and $P$. cuniculorum, one cestode species - larval form of Taenia pisiformis - Cysticercus pisiformis and one arthropode - larval form of Linguatula serrata - Pentastomum denticulatum (Table 1).

Table 1. Distribution of the parasite infections in the lungs of brown hares from Bulgaria

\begin{tabular}{|c|c|c|c|c|c|c|c|c|c|c|c|}
\hline \multirow[t]{2}{*}{ District } & \multirow[t]{2}{*}{$\mathrm{N}$} & \multirow[t]{2}{*}{$\mathrm{N}+$} & \multirow{2}{*}{$\begin{array}{l}\text { General } \\
\text { PI\% }\end{array}$} & \multicolumn{8}{|c|}{ Parasite species } \\
\hline & & & & $\begin{array}{l}P r . \\
\text { spp. }\end{array}$ & PI \% & P.d. & $\begin{array}{l}\text { PI } \\
\%\end{array}$ & $\begin{array}{l}C . \\
p .\end{array}$ & $\begin{array}{l}\text { PI } \\
\%\end{array}$ & $\begin{array}{l}\text { Pr.t. }+ \\
\text { P.d. }\end{array}$ & $\begin{array}{l}\text { PI } \\
\%\end{array}$ \\
\hline \multicolumn{12}{|c|}{ North West region } \\
\hline Vidin & 9 & - & - & - & - & - & - & - & - & - & - \\
\hline Vratsa & 25 & - & - & - & - & - & - & - & - & - & - \\
\hline Lovech & 4 & - & - & - & - & - & - & - & - & - & - \\
\hline Pleven & 50 & - & - & - & - & - & - & - & - & - & - \\
\hline \multicolumn{12}{|c|}{ North Central region } \\
\hline $\begin{array}{l}\text { Veliko } \\
\text { Tarnovo }\end{array}$ & 6 & - & - & - & - & - & - & - & - & - & - \\
\hline Razgrad & 6 & - & - & - & - & - & - & - & - & - & - \\
\hline Ruse & 2 & - & - & - & - & - & - & - & - & - & - \\
\hline Targovishte & 1 & - & - & - & - & - & - & - & - & - & - \\
\hline \multicolumn{12}{|c|}{ North East region } \\
\hline Varna & 13 & 2 & 15.38 & 2 & 15.38 & - & - & - & - & - & - \\
\hline Dobrich & 69 & 7 & 10.14 & 5 & 7.25 & 1 & 1.45 & 1 & 1.45 & - & - \\
\hline Silistra & 34 & 4 & 11.76 & 2 & 5.88 & - & - & 2 & 5.88 & - & - \\
\hline Shumen & 29 & 1 & 3.45 & 1 & 3.45 & - & - & - & - & - & - \\
\hline \multicolumn{12}{|c|}{ South West region } \\
\hline Blagoevgrad & 18 & 4 & 22.22 & 4 & 22.22 & - & - & - & - & - & - \\
\hline Sofia-city & 1 & 0 & - & - & - & - & - & - & - & - & - \\
\hline Sofia & 7 & 0 & - & - & - & - & - & - & - & - & - \\
\hline \multicolumn{12}{|c|}{ South Central region } \\
\hline Kardzhali & 4 & 0 & - & - & - & - & - & - & - & - & - \\
\hline Pazardzhik & 28 & 2 & 7.14 & - & - & - & - & 2 & 7.14 & - & - \\
\hline Plovdiv & 111 & 17 & 15.32 & 14 & 12.61 & 1 & 0.90 & 3 & 2.70 & 1 & 0.90 \\
\hline Smolyan & 5 & 2 & 40.00 & 2 & 40.00 & - & - & - & - & - & - \\
\hline Haskovo & 18 & 2 & 11.11 & 2 & 11.11 & - & - & - & - & - & - \\
\hline \multicolumn{12}{|c|}{ South East region } \\
\hline Burgas & 115 & 18 & 15.65 & 12 & 10.43 & 4 & 3.48 & 4 & 3.48 & 2 & 1.74 \\
\hline Sliven & 76 & 7 & 9.21 & 4 & 5.26 & 1 & 1.32 & 2 & 2.63 & - & - \\
\hline Stara Zagora & 92 & 15 & 16.30 & 10 & 10.87 & - & - & 5 & 5.43 & - & - \\
\hline Yambol & 67 & 7 & 10.45 & 2 & 2.99 & - & - & 5 & 7.46 & - & - \\
\hline Total: 24 & 790 & 88 & 11.14 & 60 & 7.59 & 7 & 0.89 & 24 & 3.04 & 3 & 0.38 \\
\hline
\end{tabular}

$\mathrm{N}$ : number of investigated lungs; $\mathrm{N}+$ : number of parasitised lungs; PI : prevalence of infection; $P r$. spp.: Protostrongylus spp.; P.d.: Pentastomum denticulatum; C. p.: Cysticercus pisiformis; Pr.t.: Protostrongylus tauricus. 


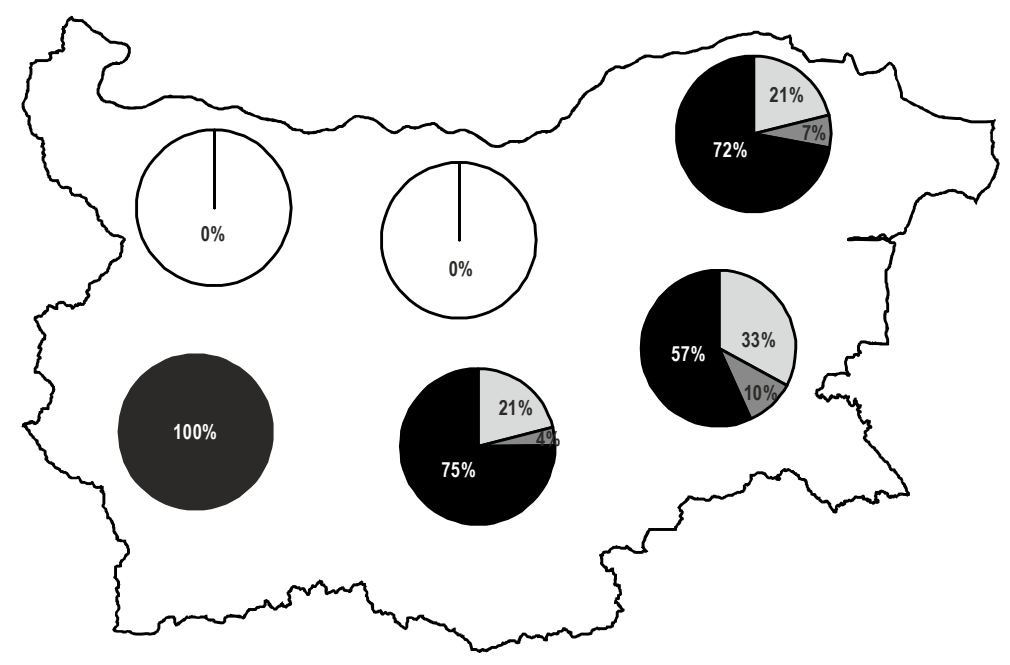

Fig. 1. Distribution of parasitic infections of the lungs in brown hares from Bulgaria. White - no parasite in the lungs; light gray - C. pisiformis; dark gray - P. denticulatum; black Protostrongylus sp.

Parasites in the lungs have been registered in brown hares from 13 of the 24 studied districts. According to the general prevalence of infection these districts are arranged in the following ascending order: Shumen, Pazardzhik, Sliven, Dobrich, Yambol, Haskovo, Silistra, Plovdiv, Varna, Burgas, Stara Zagora, Blagoevgrad and Smolyan. Considering these districts as a part of larger geographic regions (North East, North Central, North West, South East, South Central, South West), it could be assumed that there were no parasites in the lungs of hares from two regions - North West and North Central. The general prevalence of parasite infection in the North East region was 9.66\%. It was higher in the southern regions $13.43 \%$ for the South East region, 13.86\% for the South Central region and $15.38 \%$ for the South West region. Distribution of the different parasite species in these regions is shown on Fig. 1.

The prevalence of infection with the different parasite species in the male and female hares is presented in Table 2. The results clearly showed prevalence of general infestation of the lungs in female animals. This trend was also observed regarding protostrongylids. However, in relation to other parasite species, we cannot affirm it because of the small number of positive samples included in the dataset.

The results about parasitising of hares of different ages is presented in Table 3 . They show that animals up to 3 months of age remained non-infected. The parasitising of the lungs began after the fourth month of age. The general prevalence of parasite infection was the highest in the age groups of 4 to 6 months and over 3 years. This was also the trend for protostrongylid infections. With respect to $C$. pisiformis, hares between 10 and 12 months of age were the most affected. Infection with $P$. denticulatum was found only in three of the age categories: from 7 to 9 months, from 1 to 2 years, and from 2 to 3 years. 
Epidemiology of lung parasites of European brown hare (Lepus europeus L.) from Bulgaria

Table 2. Parasite infections in the lungs of brown hares from Bulgaria - influence of the sex

\begin{tabular}{lll}
\hline & Male & Female \\
\hline Number of investigated lungs & 294 & 374 \\
Number of parasitised lungs & 29 & 52 \\
General prevalence of infection & $9.86 \%$ & $13.90 \%$ \\
Number of lungs with Protostrongylus sp. & 19 & 33 \\
Prevalence of Protostrongylus sp. infection & $6.46 \%$ & $8.82 \%$ \\
Number of lungs with P. denticulatum & 1 & 1 \\
Prevalence of P. denticulatum infection & $0.34 \%$ & $0.27 \%$ \\
Number of lungs with Protostrongylus sp.+ P. denticulatum & 1 & - \\
Prevalence of Protostrongylus sp. + P. denticulatum infection & $0.34 \%$ & - \\
Number of lungs with C. pisiformis & 8 & 7 \\
Prevalence of C. pisiformis infection & $2.72 \%$ & $1.87 \%$ \\
\hline
\end{tabular}

Table 3. Parasite infections in the lungs of brown hares from Bulgaria - age dynamics

\begin{tabular}{|c|c|c|c|c|c|c|c|}
\hline Age & $\begin{array}{l}0-3 \\
\text { mo }\end{array}$ & $\begin{array}{l}4-6 \\
\text { mo }\end{array}$ & $\begin{array}{l}7-9 \\
\text { mo }\end{array}$ & $\begin{array}{l}10-12 \\
\text { mo }\end{array}$ & $\begin{array}{l}1-2 \\
\text { years }\end{array}$ & $\begin{array}{l}2-3 \\
\text { years }\end{array}$ & $\begin{array}{l}>3 \\
\text { years }\end{array}$ \\
\hline Number of investigated lungs & 14 & 85 & 218 & 71 & 120 & 229 & 27 \\
\hline Number of parasitised lungs & - & 14 & 14 & 6 & 17 & 31 & 5 \\
\hline $\begin{array}{l}\text { General prevalence of infec- } \\
\text { tion }\end{array}$ & - & $16.47 \%$ & $6.42 \%$ & $8.45 \%$ & $14.17 \%$ & $13.54 \%$ & $18.52 \%$ \\
\hline $\begin{array}{l}\text { Number of lungs with Pro- } \\
\text { tostrongylus sp. }\end{array}$ & - & 10 & 10 & 2 & 12 & 22 & 4 \\
\hline $\begin{array}{l}\text { Prevalence of Protostrongy- } \\
\text { lus sp. infection }\end{array}$ & - & $11.76 \%$ & $4.59 \%$ & $2.82 \%$ & $10.00 \%$ & $9.61 \%$ & $14.81 \%$ \\
\hline $\begin{array}{l}\text { Number of lungs with } P \text {. } \\
\text { denticulatum }\end{array}$ & - & - & 1 & 0 & 2 & 4 & 0 \\
\hline $\begin{array}{l}\text { Prevalence of } P \text {. denticula- } \\
\text { tum infection }\end{array}$ & - & - & $0.46 \%$ & - & $1.67 \%$ & $1.75 \%$ & - \\
\hline $\begin{array}{l}\text { Number of lungs with } C \text {. } \\
\text { pisiformis }\end{array}$ & - & 4 & 3 & 4 & 4 & 7 & 1 \\
\hline $\begin{array}{l}\text { Prevalence of } C \text {. pisiformis } \\
\text { infection }\end{array}$ & - & $4.71 \%$ & $1.38 \%$ & $5.63 \%$ & $3.33 \%$ & $3.06 \%$ & $3.70 \%$ \\
\hline $\begin{array}{l}\text { Number of lungs with Pro- } \\
\text { tostrongylus sp. }+ \text { P. denticu- } \\
\text { latum }\end{array}$ & - & - & - & - & 1 & 2 & 0 \\
\hline $\begin{array}{l}\text { Prevalence of Protostrongy- } \\
\text { lus sp. }+ \text { P. denticulatum } \\
\text { infection }\end{array}$ & - & - & - & - & $0.83 \%$ & $0.87 \%$ & - \\
\hline
\end{tabular}

\section{DISCUSSION}

Protostrongylids are parasites with a typical pulmonary localisation. This explains the fact that the major part of the hare population was affected by them $(7.59 \%$ prevalence vs $11.14 \%$ general prevalence of infection with parasites).

When our results are compared with those obtained 40 years ago for the South 
Dobrudja, covering the Varna and Dobrich districts (Genov, 1970) and Dobrich and Silistra (Genov, 1973) it is seen that the prevalence with protostrongylids established by Genov (54.28\% and 20.19\%) is several times higher than that registered by us for the whole country $(7.59 \%)$ as well as only for the Varna, Dobrich and Silistra districts $(7.75 \%)$. This could be due to the fact that the density of the hare population in Bulgaria 40 years ago has been significantly higher than that in recent years, which is a precondition for the wide spread of parasites among it.

It should be noted that the registered protostrongylid infections of brown hare in the present study and in a previous one (Panayotova-Pencheva et al., 2014) refer only to monoinfections. This fact confirms observations that in ruminant animals protostrongylid infections are mixed at a high percentage, whereas in wild rabbits only single infections are registered (Movsesyan et al., 2016). One of the protostrongylid species found by us was $P$. tauricus. It is acknowledged in the Bulgarian helminth-fauna since more than 4 decades (Genov, 1970). In the current study, it was the most widely recorded (7.47\% prevalence of infection). However, another protostrongylid species, identified as $P$. cuniculorum according to the morphometric features indicated by Boev (1975) was found out only in one hare $(0.13 \%$ prevalence $)$ from the Borino village (Smolyan district in the Rhodope Mountains). With this work it is registered for the first time as a part of Bulgarian helminth fauna.

The third parasite species found in the lungs of hares was $T$. pisiformis. Data on the distribution of its larval form C. pisiformis in Bulgaria are presented in the works of Yanchev $(1963 ; 1970 ; 1973)$ and Genov (1973). These authors have found the parasite in hares from the Stara Zagora region as well as some regions in South West and North Bulgaria. They have established cysticerci mainly on the seroses of abdominal organs, a localisation common to $C$. pisiformis. In the present study, we found larvae of $T$. pisiformis also under the pleura of the lungs in $3.04 \%$ of the investigated hares. This fact was attributed to the massive infection which was proved by the necropsies of the other internal organs.

The fourth parasite species established in the present study was L. serrata (as its larval forms $P$. denticulatum, which develop in the internal organs of the intermediate hosts, including humans). In our country, a massive pulmonary infection of this species has been established years ago in a brown hare from the region of Sofia (Panaiotova et al., 1999). Pentastomosis with apparent clinical signs and deaths has been recently registered also among a herd of goats near Ruse (Ivanov et al., 2012). The infection intensity with pentastomas found in the present study was low - only a few parasites in the lungs of an animal. Relatively low was also the prevalence of infection $-0.89 \%$. However, the results show that the brown hare is a natural reservoir for this parasitic disease in Bulgaria.

Here should be noted that the brown hare is probably not very important in this aspect for another, very dangerous parasitic zoonosis, such as echinococcosis. We made this assumption, as all of the 790 lungs and other internal organs of the examined hares from the whole country were free of echinococcal cysts. In his work, Yanchev (1970) also commented that although this species has been reported in helminthological literature as a parasite of rabbits, its occurrence in this host is an extremely rare phenomenon, which has 
been also supported by his results - he has found echinococcal cysts only in one hare of the total of 55 specimens studied.

The results with regard to the distribution of parasites in the different parts of the country showed that the southern districts were most affected, with the highest prevalence of infection observed in the South West geographical region, followed by South Central and South East regions. From the northern parts of the country, parasites were found only in the northeastern region - in districts situated near the Black Sea and the Danube River. In the other two regions (North Central and North Western) no parasites were found in the lungs of hares. In view of the fact that the parasites with the highest percent representation for all regions are protostrongylids, the above geographic distribution could be explained by the warmer and humid climate in the affected areas. It contributes on the one hand to the survival and activity of the first stage larvae of protostrongylids and, on the other hand, to the development of the mollusks, which are their intermediate hosts.

Regarding the influence of the age of the animals on the parameters of invasion, the following was observed: Infection with protostrongylids and cysticerci was established at the earliest in the hares aged 4-6 months and with $P$. denticulatum - in the hares between 7 and 9 months. The prevalence of infection with parasites varied in animals of different age groups. The highest general prevalence of infection was seen in the groups 4-6 months and over 3 years. According to the statistical results about the normal distribution of the hares in age groups, the probability for shooting hares from groups 4-6 months and over 3 years was smaller than this for hares from groups 7-9 and 10-12 months. Despite that the general prevalence of infection in the first two groups was higher. This points outs that the present results about the prevalence of infection in the different age groups are statistically significant. The prevalence of infection with protostrongylids varied in the same way as the general one. The peak in the prevalence of infection with protostrongylids in young animals is explained by the weak immune response to parasitic agents at this age, whereas in adults it is the result of an accumulation of invasion over the time. Accumulation of protostrongylid infection with increasing age of the hosts is also evidenced by previous studies of ours on a goat herd, in which we had established increase of protostrongylid larval output with increasing age of the animals (Panayotova-Pencheva, 2005) as well as by the results of Chroust et al. (2012) reporting that lungworms Protostrongylus pulmonalis and pneumonia findings were significantly less prevalent in sub-adult than adult brown hares. Highest prevalence of infection with cysticerci was found in hares between 10-12 months of age. This observation correlates with the results of Keith et al. (1985), who found the maximum prevalence of $T$. pisiformis in snowshoe hares at about 1 year of age.

The present study showed that the prevalence of infection with parasites affecting the lungs of the brown hare in females was 1.4 times higher as compared to that of males. The difference in the prevalence of infection between sexes was statistically significant. This prevalence in the infestation of females could be due to the weakening of the organism as a result of the physiological stress associated with the pregnancies and births. Confirmation of this hypothesis is found in the work of Molina et al. (1999) who have established a significantly higher prevalence of the 
tapeworm Andrya cuniculi in lactating and pregnant wild rabbits compared with non-breeding females.

\section{REFERENCES}

Alzaga, V., J. Vicente, D. Villanua, P. Acevedo, F. Casas \& C. Gortazar, 2008. Body condition and parasite intensity correlates with escape capacity in Iberian hares (Lepus granatensis). Behavioral Ecology and Sociobiology, 62, 769.

Boev, S. N., 1975. Protostrongylids. In: Introduction of Nematodology, ed. K. Rijikov, Moscow (RU).

Chaignat, V., P. Boujon, C.F. Frey, B. Hentrich, N. Müller \& B. Gottstein, 2015. The brown hare (Lepus europaeus) as a novel intermediate host for Echinococcus multilocularis in Europe. Parasitology Research, 114, 3167-3169.

Chroust, K., M. Vodnansky \& J. Pikula, 2012. Parasite load of European brown hares in Austria and the Czech Republic. Veterinarni Medicina, 57, 551-558.

Cuervo, P. F., S. D. Cataldo, M. C. Fantozzi, E. Deis, G. D. Isenrath, G. Viberti, P. Artigas, R. Peixoto, M. A. Valero, R.M. Sierra \& S. Mas-Coma, 2015. Liver fluke (Fasciola hepatica) naturally infecting introduced European brown hare (Lepus europaeus) in northern Patagonia: Phenotype, prevalence and potential risk. Acta Parasitologica, 60, 536-543.

Genov, T., 1970. A new and dangerous parasite in rabbits of this country. Priroda, 19, 65-68. (BG).

Genov, T., 1973. Helminthfauna of the rabbit (Lepus europeus Pall.) of Southern Dobrudja and its ecologic analysis. Scientific Works of Higher Institute of Agriculture “G. Dimitrov", 23, 709-725 (BG).

Keith, L. B., J. R. Cary, T. M. Yuill \& I. M. Keith, 1985. Prevalence of helminths in a cyclic snowshoe hare population. Journal of Wildlife Diseases, 21, 233-253.
Ilić, T., T. Petrović \& S. Dimitrijević, 2014. Parasitic infections of wild rabbits and hares. Veterinarski Glasnik, 68, 241-250.

Ivanov, A., Z. Kirkova, P. Iliev \& K. Uzunova, 2012. A case of Pentastomum denticulatum infection in goats. Journal of the Faculty of Veterinary Medicine of the Istanbul University, 38, 191-195.

Lesage, C., D. Jouet, C. Patrelle, J. Guitton, A. Decors \& H. Ferte, 2014. Protostrongylus pulmonalis (Frölich, 1802) and $P$. oryctolagi Baboš, 1955 (Nematoda: Protostrongylidae), parasites of the lungs of European hare (Lepus europaeus L.) in France: Morphological and molecular approaches. Parasitology Research, 113, 2103-2111.

Molina, X., J. C. Casanova \& C. Feliu, 1999. Influence of host weight, sex and reproductive status on helminth parasites of the wild rabbit, Oryctolagus cuniculus, in Navarra, Spain. Journal of Helminthology, 73, 221-225.

Movsesyan, S. O., M. S. PanayotovaPencheva, A. W. Demiaszkiewiz \& M. V. Voronin, 2016. Host-based formation of fauna of lung helminths, its biological and taxonomic classification. Russian Journal of Parasitology, 37, 345-369.

Panayotova-Pencheva, M. 2005. Epidemiological studies on helminthoses in goats and sheep caused by Protostrongylidae Leiper, 1926. Veterinarski Glasnik, 5/6, 619-633.

Panayotova-Pencheva, M. 2011. Species composition and morphology of protostrongylids (Nematoda: Protostrongylidae) in ruminants from Bulgaria. Parasitology Research, 109, 1015-1020.

Panaiotova, M., T. Mutafova, V. Radev, I. Kanev \& M. Nestorov, 1999. Some data of the morphology of Linguatula serrata Frölich, 1789 and clinical symptoms of disease. Experimental Pathology and $\mathrm{Pa}$ rasitology, 2, 55-59.

Panayotova-Pencheva, M., A. Trifonova, R. Mirchev, Ch. Zhelev \& D. Salkova, 2014. Actual data on Protostrongylus tauricus 
(Nematoda: Protostrongylidae) in materials from Bulgaria. In: Proceedings of the International Scientific Conference: "20 years Faculty of Veterinary Medicine at the University of Forestry", Yundola, Bulgaria, pp. 238-244. (BG).

Trifonova, A. \& R. Mirchev, 2013. Serological surveys on the prevalence of brucellosis in European brown hare (Lepus europeus, Linnaeus, 1758) from Bulgaria. International Scientific On-line Journal "Science \& Technologies", Stara Zagora, 3, 32-37 (BG).

Yanchev, Y., 1963. Untersuchungen uber die helminthenfauna des feldhasen (Lepus europeus Pall.) in Bulgarien. II. Materialen uber die helminthenfauna des feldhasen (Lepus europeus Pall.) in Stara Zagora und Nova Zagora. Bulletin de l'Institut de Zoologie et Musée, 14, 205210 (BG).

Yanchev, Y., 1970. Untersuchungen uber die helminthenfauna des feldhasen (Lepus europeus Pall.) in Bulgarien. III. Materialen uber die helminthenfauna des feldhasen (Lepus europeus Pall.) in Sudwestbulgarien. Bulletin de l'Institut de Zoologie et Musée, 32, 107-115 (BG).

Yanchev, Y., 1973. Untersuchungen uber die helminthenfauna des feldhasen (Lepus europeus Pall.) in Bulgarien. Materialen uber die helminthenfauna des feldhasen (Lepus europeus Pall.) in Nordbulgarien.
Bulletin de l'Institut de Zoologie et Musée, 38, 67-75 (BG).

Zhelev, Ch., 2015. Status and influence of some ecological factors on the stocks of brown hare (Lepus europaeus Pallas, 1778) in lowland habitats in Bulgaria. Ph.D. thesis, University of Forestry, Sofia (BG).

Paper received 23.01.2018; accepted for publication 16.03.2018

\section{Correspondence:}

Assoc. Prof. Mariana Panayotova-Pencheva Institute of Experimental Morphology,

Pathology and Anthropology with Museum Bulgarian Academy of Sciences Acad. G. Bonchev St., Block 25 1113 Sofia, Bulgaria e-mail: marianasp@abv.bg 